Article

\title{
Donor Reaction to Non-Financial Information Covering Social Projects in Nonprofits: A Spanish Case
}

\author{
José Miguel Tirado-Beltrán ${ }^{1,2}$, Iluminada Fuertes-Fuertes ${ }^{1,2} \mathbb{D}$ and J. David Cabedo ${ }^{1,2, * \mathbb{D}}$ \\ 1 Department of Finance and Accounting, Jaume I University, 12071 Castelló de la Plana, Spain; \\ tirado@uji.es (J.M.T.-B.); ifuertes@uji.es (I.F.-F.) \\ 2 Institute for Local Development (IIDL), Jaume I University, 12071 Castelló de la Plana, Spain \\ * Correspondence: cabedo@uji.es
}

Received: 14 October 2020; Accepted: 30 November 2020; Published: 4 December 2020

check for updates

\begin{abstract}
The notion of accountability in nonprofits suggests that these organisations should disclose financial and non-financial practices following a holistic model. In practice, the interest of both managers and researchers has focused primarily on donors and financial disclosures, for funding and methodological reasons respectively. From the perspective of impact investment, all of them, government, beneficiaries, private donors, managers and volunteers are expected to make their decisions based on non-financial information as investors expecting social returns. However, to what extent does project information that demonstrates that the non-profit organisation has achieved its social mission actually matter? The main objective of this paper is to analyse whether the donations received by non-governmental organisations NGOs are related to the information disclosed on the projects undertaken. We perform our analysis separately for individual, private and public donors. Our results show that public donors are more interested in financial disclosures, private donors find information about outcomes and impacts to be most useful and individual donors do not tend to use non-financial information when it comes to making decisions about whether to donate or not.
\end{abstract}

Keywords: donors; nonprofits; social projects; non-financial information

\section{Introduction}

To what extent does project information that demonstrates that a non-profit organization has achieved its social mission actually matter? There is a great deal of literature on the importance of financial information [1-4], due to the availability of financial data, but there few studies have addressed the usefulness of non-financial information, especially that which refers to the portfolio of non-profit projects and activities but paradoxically, these are their real raison d'être.

Nonprofits, unlike for-profit organisations, rely primarily on their social dimension [5]. The projects undertaken by NGOs always pursue social and/or environmental goals, so these projects make a positive contribution to sustainability. Indeed, their stakeholders could be considered as investors in social/environmental impact investors [5]. "Sustainability reporting offers a number of financial and social advantages, including social impact that builds trust towards the idea of civil society and its funders" [6]. Accountability and transparency should involve all stakeholders in a balanced manner, in addition to enabling continuous learning and disclosing financial information about projects and impacts to the same extent for all stakeholders $[7,8]$.

However, transparency and accountability practices are hierarchical [9], strongly marked by a dependence on financial resources and oriented mainly towards donors [10]. Sometimes, this pressure even encourages financial misreporting [11-13]. 
Several works have studied the usefulness of financial and non-financial information for fundraising purposes [4,14-16]. With respect to non-financial information, the literature reveals the usefulness for donors of performance disclosure (i.e., information about mission, vision, targets, strategic plan, projects, ...). There is a positive relationship between the disclosure of this information and the amount of donations received by the organisation $[17,18]$. Nevertheless, none of the previous studies have focused on the relationship between project information and donations. Given that this information is what gives the true measure of the degree of fulfilment of the social mission, it is surprising how little interest the analysis of the usefulness of this information has aroused, mainly due to the non-availability of data.

In order to shed light on the usefulness of information for donor decision-making, this study specifically analyses data on projects and activities developed by non-profits, unlike most research based on financial data. Specifically, the main objective of this paper is to analyse whether the donations received by NGOs are related to the information disclosed on the projects undertaken. In this way, we can infer the usefulness for donors of the information disclosed about these projects.

To answer this question, this study examines the corporate reports of non-profits listed by the Spanish Development NGO Coordinator (CONGDE) in 2015. Other authors $[18,19]$ have analysed the relationship between donations and the information disclosed by NGOs in different countries (Italy, UK and the USA). All of them have considered the set of donors as a whole. We, however, analysed the three categories of donors separately: individual, private and public. This is one of the contributions of our paper.

The results show that this information is useful for public donors, especially the financial content, while private donors prefer to rely on corporate information related to the outcomes and impact of the project. Conversely, individual donors do not take this corporate information into consideration.

The rest of this work is structured as follows: the next section provides the theoretical framework, the following sections present the research design, results and discussion and finally conclusions and avenues for future research.

\section{Information for Decision-Making in Non-Profits: Theoretical Framework and Development of Hypotheses}

\subsection{Motivations for Financial and Non-Financial Information Disclosure}

Several conceptual theories try to explain how non-profits disclose information among their stakeholders taking into account their primarily social mission: institutional theory, legitimacy theory, resource dependence theory and stakeholder theory $[7,20,21]$. These theories also help to understand the different approach to accountability (holistic vs. hierarchical), its prevalence in financial disclosure practices as well as the transparency policy $[7,22]$.

Accountability and transparency are concepts that are closely related to each other [22-26] and to the decision-making process in nonprofits. They require both robust financial information and non-financial information covering activities and projects [27]. As pointed out by Ebrahim [24], due to their special nature, nonprofits are expected to be accountable for multiple purposes (finances, governance, performance and mission) to different stakeholders (government, beneficiaries, private donors, board members, volunteers, employees and citizens).

These stakeholders donate, invest or lend not only money but also time, prestige, etc. [5,28,29]. However, although they expect different returns, "social impact is the goal that unifies them". Furthermore, if the concept of investment is expanded "by expanding the range of returns that investors seek and the resources they invest", they can also be considered as investors which means that they need information beyond financial data for making decisions [5] (pp. 6-27).

The entity should try to match the expectations of all its stakeholders as regards information (stakeholder theory), without prioritising financial resources providers (donors). In addition, it must be taken into account that nonprofits rely heavily on their reputation to ensure their legitimacy 
(legitimacy theory) and to protect both their financial sources (resource dependence theory) [30] and non-financial resources (such as time, expertise or reputation).

Incorporating all the above requires nonprofits to disclose both credible financial information, which is the most abundant, available and standardised, as well as reliable non-financial information (i.e., projects and social impacts) [31]. In short, this multiple stakeholder perspective requires an integrated or holistic accountability model $[7,22]$.

So far, we have considered the theory, the "what should be". However, in practice, as donations are the main source of funding for most nonprofits, these entities have mostly implemented a hierarchical and myopic accountability practice focused on donors and financial indicators [9], which leads to information asymmetries among different stakeholders [12,29]. In other words, disclosure of financial information prevails over non-financial information.

After analysing the (theoretical) reasons for nonprofits to disclose both financial and non-financial information, the (real) practice of prioritizing financial disclosure, we should now look at the motivations on which stakeholders base their decision-making.

\subsection{Information Needs for Decision-Making}

Broadly speaking, government, beneficiaries, private donors, board members, CEO and other managers, volunteers and society, in general, are the stakeholders identified in the literature [12,25,29]. From a functional point of view, each of them needs information: executives for decision-making, social workers for professional development, target groups for service improvement, funders for resourcing, regulators for accountability and society for legitimacy. From the broadest perspective of impact investment [5], as investors awaiting social performance, all of them are expected to make their decisions based largely on non-financial information (i.e., activities, projects and impacts). However, behind the philanthropic motives, there are also particular reasons that justify the different behaviours of the stakeholders. Basically, the studies explore the behaviour of donors and managers. Less interest is given to beneficiaries (as receivers of the activities and projects funded by donors) [29].

Research on the motivations of donors has attracted a great deal of attention. The studies highlight the existence of a wide range of factors behind the decision to donate. These factors can be classified as (a) factors of individuals and (b) factors of the organisation. With regard to the former, Schloderer et al. [32] stressed the importance of sociodemographic characteristics (gender, age, education and income). In this vein, Kottasz [33] points out that the higher the individual's education level, the higher the probability that he or she will make a donation. Mesch et al. [34] show that women are more altruistic and more likely to donate than men. Other papers ([35,36]) show that younger individuals are more likely to donate than older people. Bekkers and Wiepking [37] identify eight mechanisms as the most important forces driving donations (individual donors): awareness of need, solicitation, costs and benefits, altruism, reputation, psychological benefits, values and efficacy. Epstein and Yuthas [5], point to four investment returns that motivate investors: identity (reciprocity, satisfaction and reputation), process (knowledge, experience and relationships) and financial and social impact (societal and environmental).

As regards organisational factors, Scholderer et al. [32] highlighted the importance of the organisation's reputation. Parsons [4,14] showed evidence of the role of efficiency, effectiveness, financial stability and financial accounting information when making a donation decision. Trussel and Parsons [38] added that donations also depend on both the reputation of the organisation and the amount of information provided to donors. Harris and Neely [39] found evidence that donors incorporate third-party rating information (based on financial measures) into their donation decision process, and nonprofits with consistently good ratings receive higher donations. Nevertheless, other researchers such as [40] considered other aspects to be of greater utility to donors, such as familiarity, word of mouth or the visibility of the nonprofit in the community. Yan and Sloan [41] focused on the interaction between employee compensation and financial performance on donations and found that high compensations have a detrimental effect on donations except when financial performance is strong. Calabrese [42] 
showed that donations are also sensitive to the accumulation of wealth, so future contributions are negatively affected when wealth is perceived as excessive.

As can be seen, the vast majority of these studies on organisational factors underlying the decision to donate are based on financial information available in financial reports. This provides clear evidence of the utility of financial information in the donation decision process. In fact, the influence of this information is so significant, or at least managers perceive it that way, that they feel encouraged to manage financial disclosures in order to increase donations [11-13,43]. Nevertheless, few studies have addressed donation decision-making with non-financial data and their results are also inconclusive [14]. Within this field, hardly any studies have used data about the activities, projects and impacts that meet the needs of beneficiaries, even though they represent the core of the organisation. This research attempts to fill this gap.

Research on donors' perceptions reveals their interest in both financial and non-financial information $[4,14,16]$. Waniak-Michalak and Zarzycka [15] showed that Polish donors consider information about the organisation's goals and descriptions of its projects to be more useful than financial information. Saxton et al. find [17] a positive relationship between the level of donations made to US non-profits and the quantity of information these organisations provide through the web. These authors point out that the non-financial information disclosed (mission, vision, goals, strategic plans, outputs or other performance) is positively linked to donations, whilst no such relationship has been evidenced for financial information. In the same vein, Leardini et al. [18] find a similar association for US environmental nonprofits. However, these works take the disclosed information as a whole. They do not consider any kind of information about the segments that compound this information. In particular, they do not use information about activities and projects undertaken by the organisation. Therefore, empirical evidence that proves the influence of the information about activities and projects and their impacts on the donors' decision-making is lacking. The question is therefore clear: To what extent is non-financial information on activities and projects useful to donors?

\subsection{Individual, Private and Public Donors}

Organisations have stakeholders with different interests and objectives [44,45], which accounts for different information needs for decision-making. This diversity is also evident within the same group, as is the case of donors [13]. Donation decision-making differs depending on the willingness and ability of donors to search, interpret and judge the information disclosed. Based on this, [13] we distinguish between two different categories: less sophisticated donors and sophisticated donors.

Less sophisticated donors tend to be individual donors, who generally have less capacity to interpret financial information. Needless to say, there are also people who donate large sums of money. However, they usually do so indirectly, through intermediaries (trusts, foundations, or, in general terms, organisations). Therefore, we consider the latter (hereinafter referred to as Private Donors) as sophisticated donors. We assume that these Private Donors are backed by a team (as are Public Donors) that can interpret and judge the information disclosed by NGOs.

For small donors, the incremental benefit to be gained from seeking information about nonprofits in order to determine where to deposit their money is relatively low; consequently, they tend to disregard financial information when it comes to deciding on their contributions [46].

Empirical evidence on the usefulness of non-financial information for individual donors is controversial and inconclusive. Waniak-Michalak and Zarzycka [15] point out that Polish individual donors focus on non-financial information, mainly descriptive information about objectives and projects, when selecting an organisation to donate to. On the other hand, Buchheit and Parsons [47] and Parsons [4] evidence that non-financial information (service, efforts and achievements reporting) has no significant influence on actual donations.

Since the evidence is not conclusive, we based our work on the contributions of $[4,46,47]$ and therefore we do not expect individual donors to incorporate detailed non-financial information in 
their decisions to donate money. Rather, they act on the basis of more personal and emotional factors, in line with those noted by [37] awareness of need, solicitation, costs and benefits, altruism, reputation, psychological benefits, values and efficacy [40], familiarity, word of mouth or the visibility of the nonprofit in the community. In accordance with the foregoing, we propose the following hypotheses:

Hypothesis 1 (H1). The amount of donations from individual donors is not related to the information disclosed about projects. Therefore, this information is not useful for less sophisticated donors.

Private Donors and Public Donors give larger amounts and usually have greater human and technical resources than small donors, which means they have a greater capacity to interpret complex financial information and can be more sophisticated in their strategies [13]. This reasoning applies to non-financial information covering activities and projects to the full technical, financial and impact extent [31]. Corporations, foundations and grantors of legacies are more likely to study charities before donating than other individuals [46] and public donors are governmental agencies that must monitor nonprofits, given the public nature of the resources donated. This greater ability to process complex data is expected to allow sophisticated donors to incorporate non-financial information on activities and projects when making donations. Sophisticated donors do not want the funds provided to be wasted on high administration and advertising costs [48].

Hypothesis 2 (H2). The amount of donations from private donors is related to the information disclosed about projects. Therefore, this information is useful for the decision-making of private donors.

Hypothesis 3 (H3). The amount of donations from public donors is related to the information disclosed about projects. Therefore, this information is useful for the decision-making of public donors.

\section{Research Design}

\subsection{Data}

The study examines 72 corporate reports of nonprofits from the Spanish Development NGO Coordinator including top organisations. In 2015, a total of 76 non-governmental organisations were members of CONGDE. Four organisations were excluded due to a lack of data. We made a database with information about the projects undertaken by NGOs and their financial data. We obtained the data about these projects from corporate reports, available on the organisation's website, and the financial data from the CONGDE website.

\subsection{Models}

To test the hypotheses posited in the previous section, the following models (1) and (2) were used. Model 1:

$$
\ln D_{t}=\beta_{0}+\beta_{1} T I_{t-1}+\beta_{2} \ln I_{t-1}+\beta_{3} P_{R I C E} E_{t-1}+\beta_{4} F E_{t-1}+\beta_{5} \operatorname{CONCEN}_{t-1}+\varepsilon_{t}
$$

Model 2:

$$
\begin{gathered}
\ln D_{t}=\beta_{0}+\beta_{1} \text { TEC } I_{t-1}+\beta_{2} \text { FIN }_{-} I_{t-1}+\beta_{3} S C O_{I_{t-1}}+\beta_{4} \ln I_{t-1}+\beta_{5} \text { PRICE }_{t-1} \\
+\beta_{6} F E_{t-1}+\beta_{7} \operatorname{CONCEN}_{t-1}+\varepsilon_{t}
\end{gathered}
$$

where the dependent variable, $D_{t}$, denotes the funds donated in $t$. We use this notation to represent three different variables, depending on the analysed donor: individual donors $\left(I N D_{-} D_{t}\right)$, private donors $\left(P R I V \_D_{t}\right)$ or public donors $\left(P U B_{-} D_{t}\right)$. $T I_{t-1}$ is the transparency index based on information about the different projects carried out in $t-1$. See below its calculation procedure. $I_{t-1}$ is the amount of income obtained in $t-1$. PRICE $E_{t-1}$ is the total expense in $t-1$ divided by programme expense in $t-1$. $F E_{t-1}$ is the total fundraising expense in $t-1$ divided by the total expense in $t-1$. CONCEN $\operatorname{CO}_{t-1}$ is the 
concentration index in $t-1$. In represents the Napierian logarithm. $\mathrm{DI}_{t-1}$ represents the informational dimension of the transparency index in $t-1$.

Model 2 was estimated using each of the three dimensions separately: TEC_I, FIN_I and SCO_I, the information index of the technical dimension, of the financial dimension and of the scope dimension, respectively. See below the meaning and the calculation procedure for these dimensions.

The models were estimated by ordinary least squares (OLS).

\subsection{Dependent Variable}

The hypotheses were tested using the funds donated by the three kinds of donors as dependent variables. For Hypothesis 1, the dependent variable used was the amount of donations by individual donors, either through fundraising campaigns, regular donations or patronage payments. Hypothesis 2 was tested by taking the total donations made by companies both by granting subsidies and by contributions. Lastly, Hypothesis 3 was tested by taking the funds received by NGOs in the form of subsidies from public administration bodies.

\subsection{Independent Variables}

In order to measure the degree of disclosure of information about the projects, we used a modified version of the index proposed by [31]. The index of these authors incorporates information about projects concerning three dimensions: technical, financial and scope. However, the index only reflects the level of information transparency in a global manner, it does not take into consideration the measurement of each of the three dimensions separately. The index was therefore modified to analyse the contribution made by each of these dimensions to the transparency index. Accordingly, the modified index is as follows (3):

$$
T I=\frac{\sum_{i=1}^{N_{T D}} T D I_{i} / N_{T D}+\sum_{j=1}^{N_{F D}} F D I_{j} / N_{F D}+\sum_{k=1}^{N_{S D}} S D I_{k} / N_{S D}}{D}
$$

where $\mathrm{D}$ is the number of dimensions. $T D I_{i}, F D I_{j}$ and $S D I_{k}$ : must be calculated according to (4), (5) and (6):

$$
\begin{aligned}
T D I_{i} & =\frac{N T P(i)}{T N P} \\
T D I_{i} & =\frac{N T P(i)}{T N P} \\
S D I_{k} & =\frac{N S P(k)}{T N P}
\end{aligned}
$$

TNP is the number of projects carried out by the NGO within the period and NPT(i), NPF(j) and $N S P(k)$ represent the number of projects in which the NGO publishes information about the $i$-th, $j$-th and $k$-th items of, respectively:

- The technical dimension: the level of information published by the NGO related to the description of the projects carried out within the period.

- The financial dimension, which incorporates information about the financial aspects of each of the projects.

- The scope dimension, which covers aspects of the outcomes and impacts of the projects.

- $\quad N_{T D}, N_{F D}$ and $N s_{D}$ are the numbers of items in each of the dimensions.

We used the items proposed by [31] to build the transparency index. Table 1 shows the items used in each of the dimensions of the index. 
Table 1. Items analysed in the projects.

\begin{tabular}{|c|c|}
\hline Dimension & Item \\
\hline Technical & $\begin{array}{l}\text { - A description of the projects undertaken } \\
\text { - } \quad \text { Information about the action to which the project belongs } \\
\text { - } \quad \text { Information is provided about the geographical area in which the project is carried out }\end{array}$ \\
\hline Financial & $\begin{array}{l}\text { - Information about the amount of financial resources consumed by the project. } \\
\text { - } \quad \text { Details of the different sources of funding for the project. } \\
\text { - Information about the amount donated to the project by each of the sources of funding. } \\
\text { Information about the counterparty. }\end{array}$ \\
\hline Scope & $\begin{array}{l}\text { - Information about the beneficiaries of the project (qualitative information). } \\
\text { - Information about the beneficiaries of the project (quantitative information). } \\
\text { - Information about the direct and indirect beneficiaries of the project. } \\
\text { - Information about the social impact of the project. }\end{array}$ \\
\hline
\end{tabular}

The proposed index (3) will have a minimum value of 0 for those cases in which no information is offered about the projects and a maximum value of 1 for maximum information disclosure. Additionally, this index allows the separate assessment of the informational disclosure of each of the three different dimensions, as expressions (7) to (9) show:

$$
\begin{gathered}
\text { TEC_I }=\frac{\sum_{i=1}^{N_{T D}} T D I_{i}}{N_{T D}} \\
\text { FIN_I }=\frac{\sum_{j=1}^{N_{F D}} F D I_{j}}{N_{F D}} \\
\text { SCO_I }=\frac{\sum_{k=1}^{N_{S D}} S D I_{k}}{N_{S D}}
\end{gathered}
$$

\subsection{Control Variables}

Previous research has identified different factors that influence donors when it comes to making donations to nonprofit organisations. In this regard, Trussel and Parsons [38] point out that the efficiency of the allocation of resources to programmes, the organisation's financial stability, reputation and availability of information are factors that are related to the contributions donors make to nonprofits. In the models estimated to test the different hypotheses (1) and (2), a control variable was introduced for each of the factors highlighted by [38]. Efficiency was measured using the variable price of output (PRICE), which is defined by [49] as the cost for a donor of buying one dollar of output for the beneficiaries of the organisation. This variable PRICE is measured as the inverse of the programme ratio. Thus, high values of these variables mean that a large part of the funds was devoted to administrative management or fundraising instead of covering the true mission. Previous empirical studies [50-52] offer evidence of a negative relationship between PRICE and donor contributions to non-governmental organisations: on average the most efficient non-governmental organisations (small PRICE values) present greater contributions than less efficient organisations (high PRICE values) [38].

The income concentration index (CONCEN) proposed by Tuckman and Chang [53] was used as a measure of financial stability. This index is calculated in the following way (10):

$$
\operatorname{CONCEN}_{i}=\sum_{j=1}^{K}\left(\frac{F_{j}}{T F}\right)^{2}
$$

where $F_{j}$ are the funds obtained from each of the " $k$ " types of funding sources, and TF is the total amount of funding obtained in the period. This index reflects the degree of independence that nonprofits have 
on the types of funds received by these organisations. When the index has a value $=1$ means that the organisation finances itself with one source of funding. In contrast, when the value is close to zero, the organisation has balanced funding through different sources. Chang and Tuckman [54] noted that nonprofits that have diverse sources of income are more likely to be in a more stable (stronger) financial position than those with highly concentrated sources of income. Parsons and Trussel [55] showed evidence of a positive relationship between the degree of financial stability and the sum total of the donations. Donors prefer organisations with a stable financial structure, even though they might temporarily have financial problems.

Donors require information about the organisation's mission and about the activities to which it will devote their funds to. In this regard, $[46,49,56]$ used fundraising expenditure as a proxy of the information available, and found a positive relationship between this expenditure and the number of donations. We used the percentage of expenditure on fundraising out of the total spending as a proxy of the information available.

Lastly, size was taken as a proxy of reputation, as suggested by [38], using the sum total of income.

\section{Results and Discussion}

\subsection{Descriptive Statistics}

Table 2 shows descriptive statistics of all variables included in the analysis. As can be seen, the main source of funding of the NGOs are donations made by public organisations through subsidies (2374 thousand euros on average), with donations from individuals being the other major source of funding (2285 thousand euros on average). Contributions from private companies are of lesser significance and amount to an average of 641 thousand euros. However, it should be noted, as shown in Figure 1, that the vast majority of donations in the different modalities analysed (individual donations, private donations and public donations) are concentrated in a small number of NGOs. Specifically, $90 \%$ of NGOs obtain only $17 \%$ of all individual donations, $27 \%$ of private donations and $25 \%$ of public donations.

On average the transparency index (TI) of the activities is 0.52 . NGOs report about half the total maximum content that the index can have. It should also be noted that NGOs offer more information about the technical dimension (mean TEC_I is 0.73 ), whereas the scope dimension is the one for which the least information is disclosed (mean SCO_I is 0.39).

Table 3 shows the Pearson correlation coefficients of the independent and control variables of the models. It can be seen that the variables of the disclosure indexes for each of the dimensions (TEC_I, FIN_I and SCO_I) are highly correlated with one another. Therefore, if we incorporate the three variables jointly in the model it would introduce important multicollinearity problems. To prevent this issue from occurring, each of these variables was introduced separately into model 2 in order to determine the informational content of each of these informational dimensions. The other variables do not present any important correlations that could have an effect by introducing a multicollinearity problem. 
Table 2. Descriptive Statistics.

\begin{tabular}{|c|c|c|c|c|c|c|c|c|}
\hline Variables & Min. & 1st Q. & Median & Mean & 3rd $Q$. & P 90 & Max & SD \\
\hline$T i_{t-1}$ & 0 & 0.40 & 0.57 & 0.52 & 0.70 & 0.81 & 0.92 & 0.25 \\
\hline TEC_ $I_{t-1}$ & 0 & 0.67 & 0.84 & 0.73 & 1.00 & 1.00 & 1.00 & 0.33 \\
\hline$F I N \_I_{t-1}$ & 0 & 0.25 & 0.59 & 0.53 & 0.75 & 0.97 & 1.00 & 0.32 \\
\hline$S C O \_I_{t-1}$ & 0 & 0.00 & 0.39 & 0.32 & 0.50 & 0.63 & 1.00 & 0.27 \\
\hline PRICE $_{t-1}$ & 1 & 1.08 & 1.16 & 1.33 & 1.26 & 1.53 & 5.74 & 0.75 \\
\hline$F E_{t-1}$ & 0 & 0.00 & 0.00 & 0.04 & 0.03 & 0.12 & 0.57 & 0.09 \\
\hline CONCEN $_{t-1}$ & 0.26 & 0.46 & 0.59 & 0.64 & 0.85 & 0.93 & 1.00 & 0.22 \\
\hline$I N D_{-} D_{t}$ (in thousands of $€$ ) & 0 & 21 & 145 & 2285 & 607 & 8768 & 26,910 & 5777 \\
\hline$P R I \_D_{t}$ (in thousands of $€$ ) & 0 & 23 & 99 & 641 & 413 & 1373 & 13,283 & 1846 \\
\hline$P U B \_D_{t}($ in thousands of $€)$ & 0 & 80 & 450 & 2374 & 1507 & 4155 & 77,594 & 9318 \\
\hline$I_{t-1}($ in thousands of $€)$ & 1 & 682 & 1804 & 6364 & 5269 & 15,935 & 92,897 & 13,421 \\
\hline
\end{tabular}

Note: definitions of variables-TI $T I_{t-1}=$ the information transparency index regarding the different projects carried out in year $t-1$ calculated in accordance with expression (3). $T E C \_I_{t-1}=$ information index of the technical dimension in year $t-1$, calculated in accordance with expression (7). FIN_I $I_{t-1}=$ information index of the financial dimension in year $t-1$, calculated in accordance with expression (8). SCO_I $I_{t-1}=$ information index of the scope dimension in year $t-1$, calculated in accordance with expression (9). PRICE $E_{t-1}=$ total expense to programme expense ratio in year $t-1$. $I_{t-1}=$ total income obtained in year $t-1$. $F E_{t-1}=$ total fundraising expense to total expense ratio in year $t-1$. CONCEN $N_{t-1}=$ concentration index in year $t-1$, calculated in accordance with expression (10). IND_D $D_{t}$ individual donations in current year, $t . P R I V_{-} D_{t}=$ private donations in current year, $t . P U B_{-} D_{t}=$ public donations in current year, $t$

Table 3. Pearson correlation coefficients.

\begin{tabular}{ccccccccc}
\hline Variables & $\boldsymbol{T I}_{t-\mathbf{1}}$ & TEC_I $_{t-\mathbf{1}}$ & $\boldsymbol{F I N}_{-} \boldsymbol{I}_{t-\mathbf{1}}$ & SCO_I I $_{t-\mathbf{1}}$ & $\boldsymbol{l n} \boldsymbol{I}_{t-\mathbf{1}}$ & PRICE $_{t-\mathbf{1}}$ & $\boldsymbol{F E}_{t-\mathbf{1}}$ & CONCEN $_{t-\mathbf{1}}$ \\
\hline TI $I_{t-1}$ & 1 & - & - & - & - & - & - & - \\
TEC_I $I_{t-1}$ & $0.8290^{* * *}$ & 1 & - & - & - & - & - & - \\
FIN_I $I_{t-1}$ & $0.8109^{* * *}$ & $0.4725^{* * *}$ & 1 & - & - & - & - & - \\
SCO_I $I_{t-1}$ & $0.7918^{* * *}$ & $0.5135^{* * *}$ & 0.4766 & 1 & - & - & - & - \\
$\ln I_{t-1}$ & $-0.2789^{*}$ & -0.2183. & $-0.2466^{*}$ & -0.2062. & 1 & - & - & - \\
PRICE $_{t-1}$ & 0.0981 & 0.1576 & 0.1063 & -0.0250 & -0.1438 & 1 & - & - \\
FE $E_{t-1}$ & 0.0272 & 0.1667 & -0.0838 & 0.0192 & 0.1183 & $0.5567^{* * *}$ & 1 & - \\
CONCEN $_{t-1}$ & 0.1096 & -0.0014 & 0.1472 & 0.1035 & 0.0123 & $-0.2635^{*}$ & -0.1804 & 1 \\
\hline
\end{tabular}

Note: “***”, “***, “*” and "." represent significance at $0.001,0.01,0.05$ and 0.10 respectively. Definitions of variables-TI $I_{t-1}=$ the information transparency index regarding the different projects carried out in year $t-1$ calculated in accordance with expression (3). TEC $I_{t-1}=$ information index of the technical dimension in year $t-1$, calculated in accordance with expression (7). $F I N \_I_{t-1}=$ information index of the financial dimension in year $t-1$, calculated in accordance with expression (8). SCO_I $I_{t-1}=$ information index of the scope dimension in year $t-1$, calculated in accordance with expression (9). PRICE $E_{t-1}=$ total expense to programme expense ratio in year $t-1 . \ln I_{t-1}=$ Napierian logarithm of the total income obtained in year $t-1$. $F E_{t-1}=$ total fundraising expense to total expense ratio in year $t-1 . C_{C N C E N_{t-1}}=$ concentration index in year $t-1$, calculated in accordance with expression (10). 


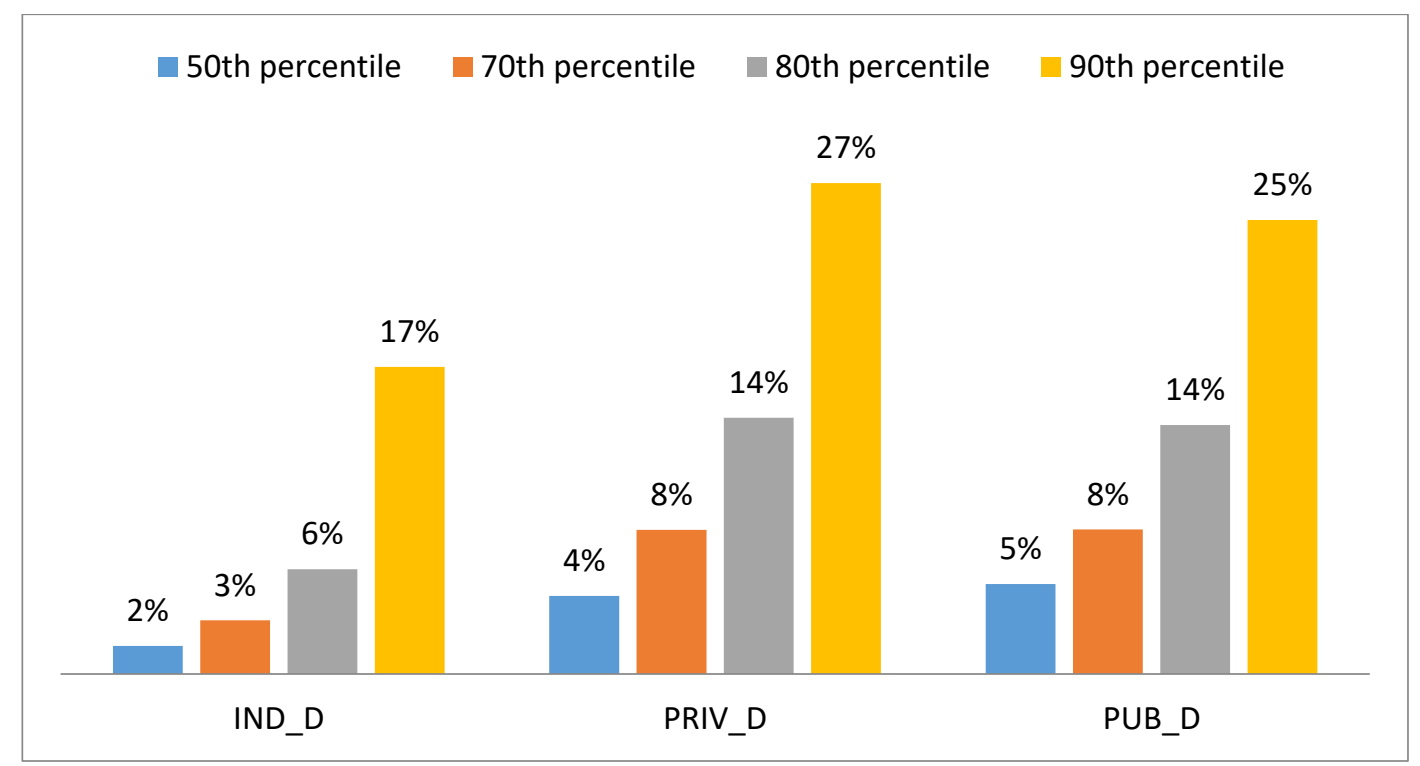

Figure 1. Distribution of the donations.

4.2. Hypothesis 1. The Amount of Donations from Individual Donors is Not Related to the Information Disclosed about Projects. Therefore, This Information is Not Useful for Less Sophisticated Donors

Table 4 shows the results of estimating the models used to test H1. Model 1 tests the relationship between donations by individual donors $\left(\ln I N D \_D\right)$ and the degree of disclosure of information about projects (TI) carried out by NGOs. The coefficient of the variable TI (-1.63) is not significant. This indicates that disclosure of information about the projects is not related to the contribution of funds by individual donors. Therefore, this information is not relevant for individual donors, as H1 posits.

Table 4. Regression Results Individual Donations.

\begin{tabular}{ccccc}
\hline \multirow{2}{*}{ Variables } & \multicolumn{2}{c}{ Model 1 } & \multicolumn{2}{c}{ Model 2 } \\
\cline { 2 - 5 } & Coeff. & Coeff. & Coeff. & Coeff. \\
\hline Intercept & -1.34 & -1.96 & -1.75 & -2.05 \\
$T I_{t-1}$ & -1.63 & - & - & - \\
TEC_It-1 & - & -0.70 & - & - \\
FIN_I $I_{t-1}$ & - & - & -1.42 & - \\
SCO_I $I_{t-1}$ & - & - & - & -1.04 \\
ln $I_{t-1}$ & $1.02 * * *$ & $1.05^{* * *}$ & $1.03^{* * *}$ & $1.04 * *$ \\
PRICE $E_{t-1}^{* * *}$ & -0.09 & -0.12 & -0.01 & -0.17 \\
FE $E_{t-1}$ & 11.21. & 11.41. & 10.17 & 11.31. \\
CONCEN $N_{t-1}$ & -2.94 & -3.13 & -2.81 & -3.05 \\
\hline Adj. $R^{2}$ & 0.26 & 0.26 & 0.26 & 0.26 \\
\hline
\end{tabular}

Note: $p$-values: “***”, “**”, “*” and “.” represent the significance at $0.001,0.01,0.05$ and 0.10 respectively. Definitions of Variables-ln IND_D $D_{t}=$ Napierian logarithm of individual donations in current year, t. $T I_{t-1}=$ the information transparency index regarding the different projects carried out in year $t-1$, calculated in accordance with expression (3). $P R I C E_{t-1}=$ total expense to programme expense ratio in year $t-1 . \ln I_{t-1}=$ Napierian logarithm of the total income obtained in year $t-1 . F E_{t-1}=$ total fundraising expense to total expense ratio in year $t-1$. $\operatorname{CONCEN}_{t-1}=$ concentration index in year $t-1$, calculated in accordance with expression (10). TEC_ $I_{t-1}=$ information index of the technical dimension in year $t-1$, calculated in accordance with expression (7). FIN $I_{t-1}=$ information index of the financial dimension in year $t-1$, calculated in accordance with expression (8). SCO_I $I_{t-1}=$ information index of the scope dimension in year $t-1$, calculated in accordance with expression (9).

Additionally, the results show that the coefficients are not significant for any of the variables that represent each of the dimensions_-technical (TEC_I), financial (FIN_I) and scope (SCO_I). This reinforces the idea that individual donors, when donating, focus mainly on personal and emotional factors 
(awareness of need, solicitation, altruism, reputation, psychological benefits, ... ) rather than on specific information about projects disclosed by NGOs in their annual reports.

In relation to the control variables, two of them (the volume of incomes and fundraising expenditure) are positive and statistically significant. This means that the higher the reputation, the higher the amount of donations $(\ln I)$. The relationship between individual donations and the volume of general information $(F E)$ has a similar meaning. These positive relationships are in line with previous literature [13,57]. On the contrary, the other two control variables (COCEN and PRICE) are not significant. We did not detect any significant relationship between the amount of individual donations, efficiency in the allocation of resources and financial stability.

4.3. Hypothesis 2. The Amount of Donations from Private Donors is Related to the Information Disclosed about Projects. Therefore, This Information is Useful for the Decision-Making of Private Donors

Table 5 shows the results of the estimation of the models used to test H2. As can be seen in Table 5 , the coefficient of TI (1.89) is not statistically significant, either. This means that the disclosure of global information about projects is not related to the contribution of funds by private donors. Nevertheless, when each of the informational dimensions is incorporated into the model separately, the results show that the coefficient of the variable scope dimension (SCO_I) (2.82) is positive and statistically significant. Not all the information about projects disclosed by NGOs is relevant for private donors. Only information about the scope dimension. Hypothesis 2 can be (at least partially) accepted.

Table 5. Regression results, private donations.

\begin{tabular}{ccccc}
\hline \multirow{2}{*}{ Variables } & Model & \multicolumn{3}{c}{ Model 2 } \\
\cline { 2 - 5 } & Coeff. & Coeff. & Coeff. & Coeff. \\
\hline Intercept & -3.79 & -4.39 & -1.56 & -4.15 \\
TI $I_{t-1}$ & 1.89 & - & - & - \\
TEC_I $I_{t-1}$ & - & 1.90 & - & - \\
FIN_I $I_{t-1}$ & - & - & -0.68 & - \\
SCO_I $I_{t-1}$ & - & - & - & 2.82 \\
In $I_{t-1}$ & $1.12^{* * *}$ & $1.13^{* * *}$ & $1.03^{* * *}$ & $1.15^{* * *}$ \\
PRICE $E_{t-1}$ & 0.17 & 0.19 & 0.27 & 0.32 \\
FE $E_{t-1}$ & 0.37 & -0.60 & 0.36 & -0.34 \\
CONCEN $N_{t-1}$ & $-4.65^{*}$ & $-4.50^{*}$ & $-4.20 *$ & $-4.73^{*}$ \\
\hline Adj. $R^{2}$ & 0.28 & 0.29 & 0.27 & 0.30 \\
\hline
\end{tabular}

Note: $p$-values: “***”, “**”, “*” and ".". Significance at $0.001,0.01,0.05$ and 0.10 respectively. Definitions of variables_ln PRIV_D $D_{t}=$ Napierian logarithm of private donations in current year, $t$. $T I_{t-1}=$ the information transparency index regarding the different projects carried out in year $t-1$, calculated in accordance with expression (3). $P R I C E_{t-1}=$ total expense to programme expense ratio in year $t-1 . \ln I_{t-1}=$ Napierian logarithm of the total income obtained in year $t-1$. $F E_{t-1}=$ total fundraising expense to total expense ratio in year $t-1$. TEC_I $I_{t-1}=$ information index of the technical dimension in year $t-1$, calculated in accordance with expression (7). FIN_I $I_{t-1}=$ information index of the financial dimension in year $t-1$, calculated in accordance with expression (8). SCO_It-1 $=$ information index of the scope dimension in year $t-1$, calculated in accordance with expression (9).

The coefficient of the control variable size $(\ln I)$ is positive and statistically significant. The interpretation of this result can be done in the same way followed in the previous section for Hypothesis 1 . However, the amount of money given by private donors is negatively related to CONCEN (in the case of individual donors the coefficient was not statistically significant). These results indicate that private donors take the financial stability of non-governmental organisations into account to make donations. When NGOs depend on one or on only a few sources of income for financing (weaker financial stability), private donors are more reluctant to donate funds. These results are consistent with [55], who showed that nonprofits with lower concentrations of income (lower CONCEN) had, on average, higher donations. The other two control variables (FE and PRICE) are not statistically significant. 
4.4. Hypothesis 3. The Amount of Donations from Public Donors is Related to the Information Disclosed about Projects. Therefore, This Information is Useful for the Decision-Making of Public Donors

Table 6 shows the results of the estimation of the models used to test H3. Like individual and private donors, the coefficient TI (0.9) is not statistically significant. This means that the disclosure of global information about projects is also not related to the contribution of funds by public donors. Nevertheless, the coefficient of the financial dimension index (FIN_I) presents a positive and significant sign (3.19). Accordingly, Hypothesis 3 is (at least partially) accepted. Not all the information on projects is relevant for public donors. Only information about financial issues. One can conclude that the disclosure of information about projects has a positive relationship with the amount of donations. Nevertheless, the results suggest that different kind of donors (private and public) focus their attention on different aspects (dimensions) of the disclosed information (scope and financial respectively).

Table 6. Regression Results Public Donations.

\begin{tabular}{ccccc}
\hline \multirow{2}{*}{ Variables } & \multicolumn{2}{c}{ Model 1 } & \multicolumn{2}{c}{ Model 2 } \\
\cline { 2 - 5 } & Coeff. & Coeff. & Coeff. & Coeff. \\
\hline \multirow{2}{*}{ Intercept } & $-9.97^{*}$ & -7.68. & -11.55 & $-8.84^{*}$ \\
TI $I_{t-1}$ & 0.90 & - & - & - \\
TEC_I $I_{t-1}$ & - & -1.21 & - & - \\
FIN_I I $I_{t-1}$ & - & - & 3.19 & - \\
SCO_I $I_{t-1}$ & - & - & - & -0.42 \\
In $I_{t-1}$ & $1.32^{* * *}$ & $1.24^{* * *}$ & $1.40^{* * *}$ & $1.28^{* * *}$ \\
PRICE $E_{t-1}$ & 0.33 & 0.37 & 0.07 & 0.33 \\
FE $E_{t-1}$ & -0.73 & 0.27 & 1.09 & -0.41 \\
CONCEN $N_{t-1}$ & 2.98 & 3.19 & 2.29 & 3.17 \\
\hline Adj. $R^{2}$ & 0.31 & 0.31 & 0.36 & 0.30 \\
\hline
\end{tabular}

Note: $p$-values: “****, “**”, “**” and "." represent significance at $0.001,0.01,0.05$ and 0.10 , respectively. Definitions of variables_ln $P U B_{-} D_{t}=$ Napierian logarithm of private donations in current year, $\mathrm{t}$. $T I_{t-1}=$ the information transparency index regarding the different projects carried out in year $t-1$, calculated in accordance with expression (3). $P R I C E_{t-1}=$ total expense to programme expense ratio in year $t-1 . \ln I_{t-1}=$ Napierian logarithm of the total income obtained in year $t-1$. $F E_{t-1}=$ total fundraising expense to total expense ratio in year $t-1$. $C O N C E N_{t-1}=$ concentration index in year $t-1$, calculated in accordance with expression (10). TEC_ $I_{t-1}=$ information index of the technical dimension in year $t-1$, calculated in accordance with expression (7). FIN $I_{t-1}=$ information index of the financial dimension in year $t-1$, calculated in accordance with expression (8). SCO $I_{t-1}=$ information index of the scope dimension in year $t-1$, calculated in accordance with expression (9).

In relation to the control variables, it should be noted that only the variable size $(\ln I)$ is positively related to the donations made by public donors. This result was interpreted in previous sections. Nevertheless, it is worth highlighting that this variable was the only statistically significant one in all the estimated models. Reputation is a key element for donors.

\subsection{Discussion}

The literature on the motivations that guide donors' behaviour in the donation decision-making process shows that there is a wide range of relevant factors that can be classified into two large groups: those attributed to individuals and related to values, attitudes and behaviours [5,32,37] and those referring to the organisation [4,14,32,39,41]. Regarding the latter, research carried out to date has proven the usefulness of disclosed financial information in the decision-making process $[4,32,38,39,41,42]$. Howbeit, some papers have recently considered whether 'disclosing is always better than non-disclosing'. In this vein, Abudy and Shust, through experimental analysis, argue that accurate rules preclude firms from disclosing questionable information [58]. Furthermore, Friedman, Hughes and Michaeli demonstrate that the strategy that an organisation follows to disclose financial information depends on two factors: the threshold that investors have (it may be high or low), and the availability of private information for these investors [59]. Nevertheless, only a few studies have 
addressed donation decision-making from a perspective primarily based on non-financial data and their results are inconclusive. Evidence shows both the importance of this type of information [14,47] and the opposite [15].

This study analysed whether non-financial information disclosed by nonprofits about activities and social projects is useful to donors in their decision-making processes. Specifically, for individual donors, our results indicate that there is no significant relationship between the volume of their donations and any of the non-financial information considered. In this regard, previous research has pointed out that non-financial disclosures do not increase actual donations $[4,18,47]$ but they can increase the percentage of potential donors. In line with Yetman and Yetman [13], this evidence among individual donors could be explained due to the fact that donation decision-making differs depending on the willingness and ability of donors to search and analyse the information. According to this, less sophisticated donors tend to be individual donors. They seem to base their decisions more on personal and emotional factors, as stressed by [37]. Results are also consistent with the line of reasoning highlighted by [47]. These results are relevant because they suggest that non-financial information about activities and projects may not always be desired or appropriate to judge the organisation. At best, it may be due to a problem of communication and reporting by the organisations. In the worst case, it means that there might be a disconnection between the projects and the organisational mission, in line with existing research [60-62].

In addition, our results show that only information about results and goals reached in the projects is taken into account by private donors to make decisions about offering financial support to NGOs. These results are consistent with [40] who revealed that charities believed that "donors place more importance on programme content and outcomes than on the reputation of the organisation in the community" when making decisions about whom to donate to. The positive sign of the relation detected allows us to conclude that more information results in a greater volume of donations.

Finally, the third hypothesis suggests a positive relationship between the information with a greater amount of financial content and the amount of donations made by public donors. The results show that public donors use the financial information of projects more than other aspects to make decisions about giving subsidies. This is not surprising since government organizations play a role in the distribution of wealth and must ensure the correct use of public funds, including those for non-profit organizations. This is why public organisations need to know how the funds allocated to each project are managed. Our results are consistent with those of those studies that argue that donors reward nonprofits that disclose large amounts of financial and performance information $[17,63,64]$. Furthermore, our results do not necessarily collide with those of [19], who do not detect any significant relationship between the financial information disclosed and the donations. These authors and, in general, all the works in previous literature, have analysed the donations as a whole, whilst our paper split those donations depending on the source from which they come.

\section{Concluding Remarks and Further Research}

This work analysed whether non-financial information disclosed by nonprofits about activities and social projects is useful to donors in their decision-making processes. The raison d'être of these nonprofits is justified by the projects they carry out and therefore, ultimately, we analysed whether donors' motivations are guided more by values and social returns than by economic reasons.

In the analysis performed, we tested whether the information disclosed about projects has an influence on the level of donations received by the nonprofit. To do so, three informational dimensions of this disclosure were taken into consideration: technical (description of the projects), financial (financial aspects of each of the projects) and scope (outcomes and impact of the project). Additionally, individual, private and public donors were studied separately. The empirical study used data for the year 2015 which was published by organisations that belong to the Spanish Development NGO Coordinator. 
Overall results show that even within the same group of stakeholders, such as that of donors, needs for information disclosed by NGOs vary according to the analytical skills or priorities of each collective. This study's findings suggest that each donor profile focuses its interest on a specific aspect to make actual donations and, therefore, they raise the question as to whether nonprofits should rethink their communication and reporting. Perhaps the one-for-all reporting model for activities and social projects, the most common among Spanish nonprofits, should be replaced by a more flexible reporting model allowing different data to be communicated to different users.

This opens up an avenue for future research on the usefulness in the decision-making of non-financial information in general, and of information covering social projects in nonprofits in particular. We are currently witnessing a great deal of interest in measuring and disclosing information about the social impact of all the different sectors (business, government, nonprofit, social enterprises, researchers). There is an abundance of studies and professional practices oriented towards calculating the impact generated fundamentally by organisations with social purposes. In essence, they correspond to the positive perception of the managers of these organisations as to the usefulness of this information for stakeholders. But do stakeholders share the same perception? Empirical evidence about the usefulness of this information for social investors or impact investors (donors, volunteers, beneficiaries, etc.) is still scarce and the results are controversial. There is still a long way to go to fill this expectation gap.

Author Contributions: Conceptualization, J.M.T.-B., I.F.-F. and J.D.C.; methodology, J.M.T.-B., I.F.-F. and J.D.C.; formal analysis, J.M.T.-B., I.F.-F. and J.D.C.; data curation, J.M.T.-B., I.F.-F. and J.D.C.; writing-original draft preparation, J.M.T.-B., I.F.-F. and J.D.C.; review \& editing, J.M.T.-B., I.F.-F. and J.D.C.; supervision, I.F.-F. and J.D.C. All authors have read and agreed to the published version of the manuscript.

Funding: This research received no external funding.

Conflicts of Interest: The authors declare no conflict of interest.

\section{References}

1. Blouin, M.C.; Lee, R.L.; Erickson, G.S. The impact of online financial disclosure and donations in nonprofits. J. Nonprofit Public Sect. Mark. 2018, 30. [CrossRef]

2. Hyndman, N. Charity accounting-An empirical study of the information needs of contributors to uk fund raising charities. Financ. Account. Manag. 1990, 6, 295-307. [CrossRef]

3. Connolly, C.; Hyndman, N. Towards Charity Accountability: Narrowing the gap between provision and needs? Public Manag. Rev. 2013, 15. [CrossRef]

4. Parsons, L.M. The Impact of Financial Information and Voluntary Disclosures on Contributions to Not-For-Profit Organizations. Behav. Res. Account. 2007, 19, 179-196. [CrossRef]

5. Epstein, M.J.; Yuthas, K. Measuring and Improving Social Impacts: A Guide for Nonprofits, Companies and Impact Investors; Greenleaf: Sheffield, UK, 2014; ISBN 978-1-907643-99-6.

6. Gazzola, P.; Amelio, S.; Papagiannis, F.; Michaelides, Z. Sustainability reporting practices and their social impact to NGO funding in Italy. Crit. Perspect. Account. 2019. [CrossRef]

7. Ebrahim, A. Accountability in Practice: Mechanisms for NGOs. World Dev. 2003, 31, 813-829. [CrossRef]

8. Jeffrey, U.; Brendan, O. Theorising accountability for NGO advocacy. Account. Audit. Account. J. 2006, 19, 349-376. [CrossRef]

9. Ebrahim, A. Accountability Myopia: Losing Sight of Organizational Learning. Nonprofit Volunt. Sect. Q. 2005, 34, 56-87. [CrossRef]

10. Sanzo-Pérez, M.J.; Rey-Garcia, M.; Álvarez-González, L.I. The Drivers of Voluntary Transparency in Nonprofits: Professionalization and Partnerships with Firms as Determinants. Volunt. Int. J. Volunt. Nonprofit Organ. 2017, 28, 1595-1621. [CrossRef]

11. Chen, Q. Director Monitoring of Expense Misreporting in Nonprofit Organizations: The Effects of Expense Disclosure Transparency, Donor Evaluation Focus and Organization Performance. Contemp. Account. Res. 2016, 33, 1601-1624. [CrossRef]

12. Hofmann, M.A.; McSwain, D. Financial disclosure management in the nonprofit sector: A framework for past and future research. J. Account. Lit. 2013, 32, 61-87. [CrossRef] 
13. Yetman, M.H.; Yetman, R.J. Do Donors Discount Low-Quality Accounting Information? Account. Rev. 2013, 88, 1041-1067. [CrossRef]

14. Parsons, L.M. Is Accounting Information from Nonprofit Organizations Useful to Donors? A Review of Charitable Giving and Value-Relevance. J. Account. Lit. 2003, 22, 104-129.

15. Waniak-Michalak, H.; Zarzycka, E. Financial And Non-financial Factors Motivating Individual Donors To Support Public Benefit Organizations. Comp. Econ. Res. 2015, 18. [CrossRef]

16. Khumawala, S.B.; Gordon, T.P. Bridging the credibility of GAAP: Individual donors and the new accounting standards for nonprofit organizations. Account. Horiz. 1997, 11, 45-68.

17. Saxton, G.D.; Neely, D.G.; Guo, C. Web disclosure and the market for charitable contributions. J. Account. Public Policy 2014, 33. [CrossRef]

18. Leardini, C.; Rossi, G.; Landi, S. Organizational factors affecting charitable giving in the environmental nonprofit context. Sustainability 2020, 12, 8947. [CrossRef]

19. Rossi, G.; Leardini, C.; Landi, S. The more you know, the more you give: Influence of online disclosure on European community foundations' donations. Nonprofit Manag. Leadersh. 2020, 31, 81-101. [CrossRef]

20. Rodríguez, M.d.M.G.; Pérez, M.d.C.C.; Godoy, M.L. Determining Factors in Online Transparency of NGOs: A Spanish Case Study. Volunt. Int. J. Volunt. Nonprofit Organ. 2012, 23, 661-683. [CrossRef]

21. Tremblay-Boire, J.; Prakash, A. Accountability.org: Online Disclosures by U.S. Nonprofits. Volunt. Int. J. Volunt. Nonprofit Organ. 2015, 26, 693-719. [CrossRef]

22. O'Dwyer, B.; Unerman, J. The paradox of greater NGO accountability: A case study of Amnesty Ireland. Account. Organ. Soc. 2008, 33, 801-824. [CrossRef]

23. Fox, J. The uncertain relationship between transparency and accountability. Dev. Pract. 2007, $17,663-671$. [CrossRef]

24. Ebrahim, A. The Many Faces of Nonprofit Accountability. In The Jossey \& Bass Handbook of Nonprofit Leadership and Management; Renz, D.O., Herman, R.D., Eds.; John Wiley \& Sons, Inc.: Hoboken, NJ, USA, 2016.

25. Rocha Valencia, L.A.; Queiruga, D.; González-Benito, J. Relationship Between Transparency and Efficiency in the Allocation of Funds in Nongovernmental Development Organizations. Volunt. Int. J. Volunt. Nonprofit Organ. 2015, 26, 2517-2535. [CrossRef]

26. Hyndman, N.; McConville, D. Transparency in Reporting on Charities' Efficiency: A Framework for Analysis. Nonprofit Volunt. Sect. Q. 2016, 45, 844-865. [CrossRef]

27. Schmitz, H.P.; Raggo, P.; Bruno-van Vijfeijken, T. Accountability of Transnational NGOs: Aspirations vs. Practice. Nonprofit Volunt. Sect. Q. 2011, 41, 1175-1194. [CrossRef]

28. LeRoux, K. Managing Stakeholder Demands. Adm. Soc. 2009, 41, 158-184. [CrossRef]

29. Wellens, L.; Jegers, M. Effective governance in nonprofit organizations: A literature based multiple stakeholder approach. Eur. Manag. J. 2014, 32, 223-243. [CrossRef]

30. Lee, C.S.; Ann, O.P.; Louise, H.S. Legitimacy, accountability and impression management in NGOs: The Indian Ocean tsunami. Account. Audit. Account. J. 2015, 28, 1075-1098. [CrossRef]

31. Cabedo, J.D.; Fuertes-Fuertes, I.; Maset-LLaudes, A.; Tirado-Beltrán, J.M. Improving and measuring transparency in NGOs: A disclosure index for activities and projects. Nonprofit Manag. Leadersh. 2018, 28, 329-348. [CrossRef]

32. Schloderer, M.P.; Sarstedt, M.; Ringle, C.M. The relevance of reputation in the nonprofit sector: The moderating effect of socio-demographic characteristics. Int. J. Nonprofit Volunt. Sect. Mark. 2014, 19, 110-126. [CrossRef]

33. Kottasz, R. How should charitable organisations motivate young professionals to give philanthropically? Int. J. Nonprofit Volunt. Sect. Mark. 2004, 9. [CrossRef]

34. Mesch, D.J.; Brown, M.S.; Moore, Z.I.; Hayat, A.D. Gender differences in charitable giving. Int. J. Nonprofit Volunt. Sect. Mark. 2011, 16. [CrossRef]

35. Pentecost, R.; Andrews, L. Differences between students and non-students' willingness to donate to a charitable organisation. Int. J. Nonprofit Volunt. Sect. Mark. 2010, 15. [CrossRef]

36. Principi, A.; Chiatti, C.; Lamura, G. Motivations of older volunteers in three European countries. Int. J. Manpow. 2012, 33. [CrossRef]

37. Bekkers, R.; Wiepking, P. A Literature Review of Empirical Studies of Philanthropy: Eight Mechanisms That Drive Charitable Giving. Nonprofit Volunt. Sect. Q. 2010, 40, 924-973. [CrossRef] 
38. Trussel, J.M.; Parsons, L.M. Financial Reporting Factors Affecting Donations to Charitable Organizations. Adv. Account. 2008, 23, 263-285. [CrossRef]

39. Harris, E.E.; Neely, D.G. Multiple Information Signals in the Market for Charitable Donations. Contemp. Account. Res. 2016, 33, 989-1012. [CrossRef]

40. Szper, R.; Prakash, A. Charity Watchdogs and the Limits of Information-Based Regulation. Volunt. Int. J. Volunt. Nonprofit Organ. 2011, 22, 112-141. [CrossRef]

41. Yan, W.; Sloan, M.F. The Impact of Employee Compensation and Financial Performance on Nonprofit Organization Donations. Am. Rev. Public Adm. 2016, 46, 243-258. [CrossRef]

42. Calabrese, T.D. Public mandates, market monitoring, and nonprofit financial disclosures. J. Account. Public Policy 2011, 30, 71-88. [CrossRef]

43. Parsons, L.M.; Pryor, C.; Roberts, A.A. Pressure to Manage Ratios and Willingness to Do So: Evidence From Nonprofit Managers. Nonprofit Volunt. Sect. Q. 2017, 46. [CrossRef]

44. Campbell, D.A.; Lambright, K.T. Program Performance and Multiple Constituency Theory. Nonprofit Volunt. Sect. Q. 2016, 45, 150-171. [CrossRef]

45. Jun, K.N.; Shiau, E. How Are We Doing? A Multiple Constituency Approach to Civic Association Effectiveness. Nonprofit Volunt. Sect. Q. 2012, 41, 632-655. [CrossRef]

46. Tinkelman, D. Differences in Sensitivity of Financial Statement Users to Joint Cost Allocations: The Case of Nonprofit Organizations. J. Accounting, Audit. Financ. 1998, 13, 377-393. [CrossRef]

47. Buchheit, S.; Parsons, L.M. An experimental investigation of accounting information's influence on the individual giving process. J. Account. Public Policy 2006, 25, 666-686. [CrossRef]

48. Chua, V.C.H.; Wong, C.M. The Role of United Charities in Fundraising: The Case of Singapore. Ann. Public Coop. Econ. 2003, 74, 433-464. [CrossRef]

49. Weisbrod, B.A.; Dominguez, N.D. Demand for collective goods in private nonprofit markets: Can fundraising expenditures help overcome free-rider behavior? J. Public Econ. 1986, 30, 83-96. [CrossRef]

50. Khanna, J.; Posnett, J.; Sandler, T. Charity donations in the UK: New evidence based on panel data. J. Public Econ. 1995, 56, 257-272. [CrossRef]

51. Marudas, N.P.; Jacobs, F.A. Effects of Nonprofit Organizational Wealth on Donations: Evidence from Recent Data on the NonProfit Times 100. Z. Offentl. Gemeinwirtsch. Unternehm. 2006, 34, 74-88.

52. Jacobs, F.A.; Marudas, N.P. the Combined Effect of Donation Price and Administrative Inefficiency on Donations To Us Nonprofit Organizations. Financ. Account. Manag. 2009, 25, 33-53. [CrossRef]

53. Tuckman, H.P.; Chang, C.F. A Methodology for Measuring the Financial Vulnerability of Charitable Nonprofit Organizations. Nonprofit Volunt. Sect. Q. 1991, 20, 445-460. [CrossRef]

54. Chang, C.F.; Tuckman, H.P. Revenue diversification among non-profits. Voluntas 1994, 5, 273-290. [CrossRef]

55. Parsons, L.M.; Trussel, J.M. Fundamental analysis of not-for-profit financial statements: An examination of financial vulnerability measures. Res. Gov. Nonprofit Account. 2009, 12, 35-56.

56. Balsam, S.; Harris, E.E. The Impact of CEO Compensation on Nonprofit Donations. Account. Rev. $2014,89$. [CrossRef]

57. Surysekar, K.; Turner, E.H. The Association Between Fundraising Efficiency, Financial Vulnerability, and Subsequent Donations to Not-For-Profits. Rev. Bus. Inf. Syst. 2012, 16, 157-164. [CrossRef]

58. Abudy, M.; Shust, E. What Happens to Trading Volume When the Regulator Bans Voluntary Disclosure? Eur. Account. Rev. 2020, 29, 555-580. [CrossRef]

59. Friedman, H.L.; Hughes, J.S.; Michaeli, B. Optimal reporting when additional information might arrive. J. Account. Econ. 2020, 69. [CrossRef]

60. AbouAssi, K. Hands in the Pockets of Mercurial Donors: NGO Response to Shifting Funding Priorities. Nonprofit Volunt. Sect. Q. 2013, 42, 584-602. [CrossRef]

61. Elbers, W.; Arts, B. Keeping body and soul together: Southern NGOs' strategic responses to donor constraints. Int. Rev. Adm. Sci. 2011, 77, 713-732. [CrossRef]

62. Rauh, K. NGOs, Foreign Donors, and Organizational Processes: Passive NGO Recipients or Strategic Actors? McGill Sociol. Rev. 2010, 1, 29-45.

63. Gandía, J.L. Internet Disclosure by Nonprofit Organizations: Empirical Evidence of Nongovernmental Organizations for Development in Spain. Nonprofit Volunt. Sect. Q. 2011, 40. [CrossRef] 
64. Harris, E.E.; Neely, D. Determinants and Consequences of Nonprofit Transparency. J. Account. Audit. Financ. 2018. [CrossRef]

Publisher's Note: MDPI stays neutral with regard to jurisdictional claims in published maps and institutional affiliations.

(C) 2020 by the authors. Licensee MDPI, Basel, Switzerland. This article is an open access article distributed under the terms and conditions of the Creative Commons Attribution (CC BY) license (http://creativecommons.org/licenses/by/4.0/). 